điểm Brixia thấp. Bệnh nhân có điểm Brixia càng cao thì càng có nhu cầu cần hỗ trợ oxy bởi các thiết bị cung cấp oxy.

\section{TÀI LIÊU THAM KHẢO}

1. Schaefer-Prokop C, Prokop M. Chest Radiography in COVID-19: No Role in Asymptomatic and Oligosymptomatic Disease. Radiology. 2021;298(3):E156-e7.

2. Akl EA, Blažić I, Yaacoub S, et al. Use of Chest Imaging in the Diagnosis and Management of COVID-19: A WHO Rapid Advice Guide. Radiology. 2021:298(2):E63-e9.

3. Martínez Chamorro $E$, Díez Tascón A, Ibáñez Sanz L, et al. Radiologic diagnosis of patients with COVID-19. Radiologia (Engl Ed). 2021;63(1):56-73.

4. Au-Yong I, Higashi $Y$, Giannotti $E$, et al. Chest Radiograph Scoring Alone or Combined with Other Risk Scores for Predicting Outcomes in COVID-19.
Radiology. 2021:210986

5. Borghesi A, Maroldi R. COVID-19 outbreak in Italy: experimental chest X-ray scoring system for quantifying and monitoring disease progression. La radiologia medica. 2020;125(5):509-13.

6. Setiawati $R$, Widyoningroem $A$, Handarini $T$, et al. Modified Chest X-Ray Scoring System in Evaluating Severity of COVID-19 Patient in Dr. Soetomo General Hospital Surabaya, Indonesia. Int J Gen Med. 2021;14:2407-12.

7. Reeves RA, Pomeranz C, Gomella AA, et al. Performance of a Severity Score on Admission Chest Radiography in Predicting Clinical Outcomes in Hospitalized Patients With Coronavirus Disease (COVID-19). AJR Am J Roentgenol. 2021;217(3):623-32.

8. Schalekamp $S$, Huisman $M$, van Dijk RA, et al. Model-based Prediction of Critical Illness in Hospitalized Patients with COVID-19. Radiology. 2021;298(1):E46-e54.

\title{
NHÂ̂N XÉT KẾT QUẢ NộI SOI U BUỒNG TRÚNG TẠI BỆNH VIỆN PHỤ SẢN THÁI BÌNH NĂM 2010 VÀ NĂM 2020
}

\section{TÓM TẮT}

Mục tiêu: Nhân xét kết quả nội soi xử trí u buồng trứng tai Bệnh viển Phu Sản Thái Bình năm 2010 và năm 2020. Đối tượng và phương pháp nghiên cứu: Hồi cứu bênh án tất cả số bênh nhân có chẩn đoán lâm sàng là u buồng trứng trong 2 giai đoạn: từ $1 / 1 / 2010$ đến $31 / 12 / 2010$ và từ $1 / 1 / 2020$ đến $31 / 12 / 2020$, đã được phẫu thuật nội soi và có chẩn đoán mô bệnh học là u buồng trứng tại Bệnh viện Phụ Sản Thái Bình. Kết quả: Tỷ lệ phẫu thuật nội soi u buồng trứng năm $2020(71.2 \%)$ cao hơn hẳn so với năm 2010 (33,3\%), với p<0,05. Năm 2010, u thanh dịch chiếm tỷ lệ cao nhất là $46,7 \%$. Năm 2020 , u bì chiếm tỷ lệ cao nhất là 39,7\%. Năm 2010, tỷ lệ cắt buồng trứng là cao nhất ở các nhóm kích thước u $<50 \mathrm{~mm}$ và $50-100 \mathrm{~mm}$. Năm 2020 tỷ lệ bóc u là cao nhất ở các nhóm kích thước u $<50 \mathrm{~mm}$ và $50-100 \mathrm{~mm}$, lần lượt chiếm tỷ lệ $89,8 \%$ và $68,4 \%$; nhóm kích thước $>100 \mathrm{~mm}$ tỷ lệ bóc u là $25,0 \%$. Thời gian phấu thuật năm 2020 ở mức độ không dính và dính ít giảm hơn so với năm 2010. Tai biến và biến chứng trong và sau phẫu thuâtt năm 2020 không có trường hợp nào. Kết luận: U buồng trứng là một trong những vấn đề hay gặp nhất trong lĩnh vực phụ khoa. Phẫu thuật nội soi ngày càng được ứng dụng rộng rãi trong xử trí u buồng trứng, đem lại lợi ích cho bệnh nhân.

Từ khóa: u buồng trứng, phẫu thuật nội soi,...

\footnotetext{
${ }^{1}$ Bệnh viện Phụ Sản Thái Bình,

2 Trường Đại hơ Y Hà Nôi

Chịu trách nhiệm chính: Đinh Thị Oanh

Email: oanhdinh1979@gmail.com

Ngày nhận bài: 12.8.2021

Ngày phản biên khoa hoc: 7.10.2021

Ngày duyệt bài: 14.10.2021
}

\section{SUMMARY \\ LAPAROSCOPY FOR OVARIAN TUMORS AT THÁI BİNH PROVINCE HOSPITAL OF OBSTETRICS AND GYNECOLOGY IN 2010 AND 2020 \\ Study Objectives: Consider surgery by} laparoscopy for ovarian tumors at Thái Bình Province Hospital of Obstetrics and Gynecology in 2010 and 2020. Subjects and methods: A retrospective study included 122 patients with ovarian tumors in 2010 and 242 patients in 2020 diagnosed and treated by laparoscopy at Thái Bình Province Hospital of Obstetrics and Gynecology. Result: In 2020, 71,2\% patients were operated by laparoscopy surgery, while $33,3 \%$ patients were surgically treated in 2010 $(p<0.05)$. In 2010, pathological result of $46,7 \%$ patients were serous tumor. In 2020, the rate of mature teratoma was highest $(39.7 \%)$. In 2010 , the rate of laparocopic oophorectomy was highest at the groups had the maximum diameter of the ovarian tumors: $<5 \mathrm{~cm}, \geq 5 \mathrm{~cm}$ but $<10 \mathrm{~cm}$. Whereas in 2020 , the rate of ovarian cystectomy was highest at this groups $(89,8 \%$ and $68.4 \%)$. The group had the maximum diameter of ovarian tumors $>100 \mathrm{~mm}$, $25,0 \%$ patient was performed by ovarian cystectomy. The surgical time with no adhesion or flimy adhesion cases in 2020 was less than time in 2010. There was no complication in during surgery and post-surgery in 2020. Conclusion: Ovarian tumors is one of the most commonly masks in women. Laparoscopic surgery is more and more widely used, bringing the benefits to the patients.

Keywords: ovarian tumor, laparoscopic surgery,...

I. ĐẶT VẤN ĐỀ

U buồng trứng (UBT) là bệnh lý phụ khoa có 
thể gặp ở mọi lứa tuổi người phụ nữ và có xu hướng gia tăng. Ở Canada, u buồng trứng đứng thứ 5 sau u vú, u đại tràng, u cổ tử cung và u thân tử cung [1]. Tại Việt Nam, u buồng trứng là loại u hay gặp trong các khối u cơ quan sinh dục nữ, chỉ đứng thứ 2 sau u cơ trơn tử cung. ở khu vực phía Bắc, u buồng trứng chiếm tỷ lệ $3,6 \%$ các khối u sinh dục [2]. Bệnh thường tiển triển lặng lẽ trong thời gian dài và không có dấu hiệu lẩm sàng điển hình, nhưng rất dễ dẫn đến các biến chứng đòi hỏi phải can thiệp như xoắn $u$, võ $u$, chảy máu trong $u$, nhiễm khuẩn $u$ hay chèn ép tiểu khung... UBT có thể gây vô sinh, gây sảy thai, dọa đẻ non, trở thành u tiền đạo ở phụ nữ có thai gây đẻ khó..., đặc biệt là nguy cơ ung thư hóa là nguyên nhân gây tử vong cho phụ nữ. Việc loại bỏ UBT được thực hiện với nhiều phương pháp khác nhau. Can thiệp kinh điển là phẫu thuật mở bụng để cắt hoặc bóc tách khối u bảo tồn nhu mô lành buồng trứng [3]], cũng có thể chọc hút nang dưới sự hướng dấn của siêu âm. Hiện nay, với sự phát triển của công nghệ, sự tiến bộ về kỹ năng của thầy thuốc, phấu thuật nội soi (PTNS) gần như được áp dụng hầu hết trong điều trị UBT lành tính. Bệnh viện Phụ Sản Thái Bình là bệnh viện chuyên khoa cao nhất của tỉnh Thái Bình được thành lập và đi vào hoạt động 20 năm qua, đã có những bước tiến rõ rệt trong chẩn đoán và điều trị, nổi trội nhất là phấu thuật nội soi. PTNS được áp dụng từ năm 2008 và ngày càng chiếm ưu thế so với mổ mở trong xử trí UBT, vừa giúp chẩn đoán các trường hợp khó, vừa có vai trò điều trị. Mổ mở thường chỉ áp dụng ở các trường hợp UBT quá dính, chảy máu nhiều hoặc có nguy cơ ác tính. Để đánh giá quá trình phát triển trong ứng dụng PTNS xử trí u buồng trứng, chúng tôi tiến hành nghiên cứu với mục tiêu: Nhận xét kết quả nội soi u buồng trứng tại Bệnh viện Phụ Sản Thái Bình năm 2010 và 2020.

\section{II. ĐỐI TƯỢNG VÀ PHƯƠNG PHÁP NGHIÊN CỨU}

2.1. Đối tượng nghiên cứu: Tất cả số bệnh nhân có chẩn đoán lâm sàng là UBT trong 2 giai đoạn: từ $1 / 1 / 2010$ đến $31 / 12 / 2010$ và từ $1 / 1 / 2020$ đến $31 / 12 / 2020$, đã được phẫu thuật nội soi và có chẩn đoán mô bệnh học là UBT tại Bệnh viện Phụ Sản Thái Bình. Năm 2010 có 122 bệnh nhân, năm 242 bệnh nhân đủ tiêu chuẩn lựa chọn.

\subsection{Phương pháp nghiên cứu}

- Thiết kế nghiên cứu: Nghiên cứu mô tả hồi cứu cắt ngang

- Xử lý số liệu: Sử dụng phần mềm SPSS 20.0 , so sánh sự khác biệt bằng test $X^{2}$

2.3. Đạo đức nghiên cứu: Nghiên cứu không can thiệp trên bệnh nhân, chỉ sử dụng hồ sơ bệnh án được lưu trữ tại kho hồ sơ của bệnh viện, đảm bảo sự bí mật thông tin. Kết quả nghiên cứu nhằm đưa ra kiến nghị để phục vụ bệnh nhân, nâng cao chất lượng điều trị.

\section{KẾT QUẢ NGHIÊN CỨU}

\subsection{Phân bố mổ u buồng trứng theo năm}

Bảng 3.1. Phân bố mổ u buồng trứng theo năm

\begin{tabular}{|c|c|c|c|c|c|}
\hline \multirow{2}{*}{ Nhương pháp PT } & \multicolumn{2}{|c|}{$\mathbf{2 0 1 0}$} & \multicolumn{2}{|c|}{$\mathbf{2 0 2 0}$} & \multirow{2}{*}{$\mathbf{p}$} \\
\cline { 2 - 5 } & $\mathbf{n}$ & $\mathbf{\%}$ & $\mathbf{n}$ & $\mathbf{\%}$ & \multirow{2}{*}{$<0,05$} \\
\hline Nội soi & 120 & 33,3 & 242 & 71,2 & \\
\hline Mổ mở & 238 & 66,1 & 98 & 28,8 & \\
\hline Nội soi chuyển mổ mở & 2 & 0,6 & 0 & 0 & \\
\hline Tống & $\mathbf{3 6 0}$ & $\mathbf{1 0 0}$ & $\mathbf{3 4 0}$ & $\mathbf{1 0 0}$ & \\
\hline
\end{tabular}

Nhận xét: - Tỷ lệ phẫu thuật nội soi u nang buồng trứng năm 2020 (71,2\%)cao hơn hẳn so với năm 2010 là 33,9\%. Tỷ lệ này khác biệt có ý nghĩa thống kê với $p<0,05$.

- Tỷ lệ nội soi chuyển mổ mở năm 2010 là 0,6\%, năm 2020 không có trường hợp nào.

\subsection{Kết quả giải phẫu bệnh}

Bảng 3.2. Kêt quả giải phẫu bệnh

\begin{tabular}{|c|c|c|c|c|c|}
\hline \multirow{2}{*}{ Loại u } & Năm & \multicolumn{2}{c|}{$\begin{array}{c}\text { Năm 2010 } \\
\mathbf{( n = 1 2 2 )}\end{array}$} & \multicolumn{2}{c|}{$\begin{array}{c}\text { Năm 2020 } \\
\mathbf{( n = 2 4 2 )}\end{array}$} \\
\cline { 3 - 6 } & & $\mathbf{n}$ & $\mathbf{\%}$ & $\mathbf{n}$ & $\mathbf{\%}$ \\
\hline \multirow{3}{*}{ U buồng trứng lành tính } & Nang thanh dịch & 57 & 46,7 & 91 & 37,6 \\
\cline { 2 - 6 } & U nang nhày & 8 & 6,6 & 12 & 5,0 \\
\cline { 2 - 6 } & Nang bì & 43 & 34,4 & 96 & 39,7 \\
\cline { 2 - 6 } & U nội màc tử cung & 14 & 11,5 & 39 & 16,1 \\
\cline { 2 - 6 } & Nang nhày giáp biê̂n & 0 & 0 & 3 & 1,2 \\
\hline U buồng trứng ác tính & Ung thư biếu mô & 0 & 0 & 1 & 0,4 \\
\hline
\end{tabular}


Nhận xét: - Năm 2010, u thanh dịch chiếm tỷ lệ cao nhất là 46,7\%. Năm 2020, u bì chiếm tỷ cao nhất là 39,7\%.

- Năm 2020, có 03 trường hợp u nhày giáp biên chiếm tỷ lệ 1,2\% và 01 trường hợp ung thư biểu mô chiếm tỷ lệ $0,4 \%$.

3.3. Phân bố xử trí u theo kích thước u

Bảng 3.3. Phân bố xử trí u theo kích thước u

\begin{tabular}{|c|c|c|c|c|c|c|c|c|}
\hline \multirow{3}{*}{ Xứ trí } & \multicolumn{2}{|c|}{$<50(\mathrm{~mm})$} & \multicolumn{2}{|c|}{$50-100(\mathrm{~mm})$} & \multicolumn{2}{|c|}{$>100(\mathrm{~mm})$} & \multicolumn{2}{|c|}{ Tống } \\
\hline & 2010 & 2020 & 2010 & 2020 & 2010 & 2020 & 2010 & 2020 \\
\hline & N (\%) & & ) & $\mathbf{N}($ & (o) & & $\%)$ & \\
\hline Bóc u & $5(20$ & $53(8$ & 16( & 117 & $0(0,0)$ & & $21(17,2)$ & $173(71,5)$ \\
\hline & $17(7$ & & 71( & & & & & \\
\hline & & & & & & & & \\
\hline & $\begin{array}{c}24 \\
(100,0)\end{array}$ & $\begin{array}{c}59 \\
(100,0)\end{array}$ & $\begin{array}{c}98 \\
(100,0)\end{array}$ & $\begin{array}{c}171 \\
(100,0)\end{array}$ & $\begin{array}{c}0 \\
(0,0)\end{array}$ & $\begin{array}{c}12 \\
(100,0)\end{array}$ & $\begin{array}{c}122 \\
(100,0)\end{array}$ & $\begin{array}{c}242 \\
(100,0)\end{array}$ \\
\hline
\end{tabular}

Nhận xét: - Năm 2010 tỷ lệ cắt buồng trứng là cao nhất ở các nhóm kích thước u <50mm và 50$100 \mathrm{~mm}$, lần lượt chiếm tỷ lệ: $70,8 \%$ và $72,4 \%$, không có trường hợp nào kích thước u $>100 \mathrm{~mm}$.

- Năm 2020 tỷ lệ bóc u là cao nhất ở các nhóm kích thước u <50mm và $50-100 \mathrm{~mm}$ lần lượt chiếm tỷ lệ: $89,8 \%$ và $68,4 \%$; nhóm kích thước $>100 \mathrm{~mm}$ tỷ lệ bóc u là $25,0 \%$.

3.4. Phân bố xử trí u theo mức độ dính

Bảng 3.4. Phân bố xứ trí u theo mức độ dính

\begin{tabular}{|c|c|c|c|c|c|c|}
\hline \multirow{2}{*}{ MĐ dính } & \multicolumn{2}{|c|}{ Không dính } & \multicolumn{2}{|c|}{ Dính ít } & \multicolumn{2}{c|}{ Dính nhî̀u } \\
\cline { 2 - 7 } Xử trí u & $\mathbf{2 0 1 0}$ & $\mathbf{2 0 2 0}$ & $\mathbf{2 0 1 0}$ & $\mathbf{2 0 2 0}$ & $\mathbf{2 0 1 0}$ & $\mathbf{2 0 2 0}$ \\
\cline { 2 - 7 } & $\mathbf{N}(\mathbf{\%})$ & $\mathbf{N}(\mathbf{\%})$ & $\mathbf{N}(\%)$ & $\mathbf{N}(\%)$ & $\mathbf{N}(\%)$ & $\mathbf{N}(\%)$ \\
\hline Bóc u & $18(17,5)$ & $127(72,5)$ & $3(17,6)$ & $45(75,0)$ & $0(0,0)$ & $1(14,3)$ \\
\hline Cắt u & $76(73,8)$ & $26(14,9)$ & $12(70,6)$ & $10(16,7)$ & $0(0,0)$ & $2(28,6)$ \\
\hline Cắt PP & $9(8,7)$ & $22(12,6)$ & $2(11,8)$ & $5(8,3)$ & $2(100,0)$ & $4(57,1)$ \\
\hline Tống & $\mathbf{1 0 3 ( 1 0 0 , 0 )}$ & $\mathbf{1 7 5 ( 1 0 0 , 0 )}$ & $\mathbf{1 7}(\mathbf{1 0 0 , 0})$ & $\mathbf{6 0}(\mathbf{1 0 0 , 0})$ & $\mathbf{2 ( 1 0 0 , 0 )}$ & $\mathbf{7 ( 1 0 0 , 0 )}$ \\
\hline
\end{tabular}

Nhận xét: - Năm 2010: Cắt buồng trứng chiếm cao nhất ở các nhóm không dính và dính ít lần lượt là: 73,8\% và 70,6\%; không phẫu thuật trường hợp nào dính nhiêu.

- Năm 2020: Bóc u chiếm tỳ lệ cao nhất ở các nhóm không dính và dính ít lần lượt là: $72,5 \%$ và 75,0\%; nhóm dính nhiêu chiếm tỷ lệ 14,3\%.

3.5. Phân bố thời gian phẫu thuất với mức độ dính của u

Bảng 3.5. Phân bốthời gian phẩu thuật với mức độ dính cuả u

\begin{tabular}{|c|c|c|c|c|c|c|c|c|}
\hline \multirow{2}{*}{$\begin{array}{l}\text { TGPT(phút) } \\
\text { Mức độ dính }\end{array}$} & \multicolumn{4}{|c|}{2010} & \multicolumn{4}{|c|}{2020} \\
\hline & $\bar{x}$ & SD & $\min$ & $\max$ & $\bar{x}$ & SD & $\min$ & $\max$ \\
\hline Khồng dính & 48,81 & 14,55 & 27 & 120 & 39,26 & 9,82 & 20 & 80 \\
\hline Dính ít & 54,33 & 9,60 & 31 & 110 & 47,76 & 18,50 & 25 & 100 \\
\hline Dính nhiều & 0,0 & 0,0 & 0 & 0 & 123,94 & 12,69 & 86,54 & 150 \\
\hline
\end{tabular}

Nhận xét: - Thời gian phầu thuật năm 2020 ở mức độ không dính và dính ít giảm hơn so với năm 2010.

- Nắm 2010 không phấu thuật trường hợp nào dính nhiêu. Có 2 trường hợp dính nhiêu khi nội soi phải chuyển sang mổ mở.

- Thời gian phẫu thuật tăng lên theo mức độ dính.

3.6. Tai biến và biến chứng

Bảng 3.6. Tai biến và biến chứng

\begin{tabular}{|c|c|c|c|c|}
\hline \multirow{2}{*}{ Nai biến và biến chứng } & \multicolumn{2}{|c|}{$2010 \mathbf{( n = 1 2 2 )}$} & \multicolumn{2}{|c|}{$\mathbf{2 0 2 0}(\mathbf{n = 2 4 2})$} \\
\cline { 2 - 5 } & $\mathbf{n}$ & $\mathbf{\%}$ & $\mathbf{n}$ & $\mathbf{\%}$ \\
\hline Có & 2 & 1,6 & 0 & 0 \\
\hline Không & 122 & 100 & 242 & 100 \\
\hline
\end{tabular}

Nhận xét: Tai biến và biến chứng trong và sau phầu thuật năm 2020 không có trường hợp nào, năm 2010 có 2 trường hợp: 1 trường hợp chảy máu sau mổ, 1 trường hợp tụ máu thành bụng lố chọc trocart.

3.7. Thời gian nằm viện sau phẫu thuâat

Bảng 3.7. Thời gian nằm viện sau phẩu thuật

\begin{tabular}{|l|l|l|l|l|}
\hline \multirow{2}{*}{ Thời gian nằm viện } & \multicolumn{2}{|c|}{2010} & \multicolumn{2}{|c|}{2020} \\
\cline { 3 - 5 }
\end{tabular}




\begin{tabular}{|c|c|c|c|c|}
\hline$\leq 4$ ngày & 64 & 52,5 & 224 & 92,6 \\
\hline 4 - 7 ngày & 58 & 47,5 & 18 & 7,4 \\
\hline Tống & 122 & 100 & 242 & 100 \\
\hline
\end{tabular}

Nhânn xét: Thời gian năm viện dưới 4 ngày năm 2020 cao hơn hằn so với năm 2010.

\section{BÀN LUÂ̂N}

4.1. Tỷ lệ phẫu thuật nội soi UBT và kêt

quả giải phẫu bệnh. Qua nghiên cứu hồi cứu hồ sơ bệnh án tại Bệnh viện Phụ sản Thái Bình trong 2 năm 2010 và 2020 , chúng tôi thấy tỷ lệ mổ u buông trứng bằng phấu thuật nội soi/ tổng số mổ UBT năm 2010 là 33,9\%, năm 2020 là $71,2 \%$. Tỷ lệ mổ UBT bằng phương pháp phẫu thuật nội soi năm 2020 tăng hơn nhiều so với năm 2010, sự khác biệt này có ý nghĩa thống kê với $p<0,05$. Sự khác biệt này đã chứng tỏ trình độ phẫu thuật nội soi ở Bệnh viện Phụ sản Thái Bình tăng lên rất nhiêu, do vậy đã chỉ định mổ nội soi u buồng trứng rộng rãi hơn. Theo Phạm Thị Thanh Quỳnh (2012), tỷ lệ phẫu thuật nội soi/tổng số mổ u buông trứng năm 2001 là 35,68\%, năm 2010 là 92,35\% [4]. Như vậy, kết quả của chúng tôi thấp hơn so với nghiên cứu của Phạm Thị Thanh Quỳnh, điều này có thể được giải thích do Phạm Thị Thanh Quỳnh nghiên cứu tại Bệnh viện Phụ sản Trung ương, nơi tuyến đâu hội tụ nhiều bác sỹ có trình độ chuyên môn giỏi, trang thiết bị hiện đại. Tuy nhiên, tỉ lệ này đã thể hiện bước tiến lớn đối với Bệnh viện Phụ Sản Thái Bình trong cập nhật kiến thức và đâu tư trang thiết bi để bệnh viện phát triển hơn nữa đáp ứng được nhu cầu chăm sóc sức khỏe của người dân theo phân cấp của bệnh viện tuyến tỉnh. Hai trường hợp nội soi phải chuyển sang mổ mở trong nghiên cứu của chúng tôi đều do khối u dính với các tạng xung quanh như đại tràng, thành chậu, ruột non. Theo Marana R. et al (2004), nguyên nhân chuyển mổ mở chủ yếu do u lạc nội mạc tử cung dính nhiều, còn lai do u bì kích thước lớn và nghi ngờ ác tính [5]. Phẫu thuật nội soi có nhiều ưu việt hơn, tuy nhiên cân phải thăm khám kĩ lưỡng trước mổ, đặt an toàn cho người bệnh lên hàng đâu, khi phẫu thuât khó khăn nhất là đối với các phẫu thuật viên mới làm nội soi chưa có nhiêu kinh nghiệm, cần chuyển mổ mở hoặc mời phẫu thuật viên có trình độ và kinh nghiệm hơn mình để tránh tai biến cho người bệnh.

Nghiên cứu của chúng tôi cho thây năm 2010 tỷ lệ u nang thanh dịch cao nhất chiếm 46,7\%; năm 2020 tỷ lệ u bì cao nhất, chiếm 39,7\%, u nang thanh dịch là $37,6 \%$. Đó là do vào những giai đoạn đâu thực hiện phẫu thuật nội soi u bì là loại u được coi là khó nên chỉ định còn hạn chế, chủ yếu chỉ định nội soi dạng u nang thanh dịch. Trong những năm gân đây trình độ, kỹ năng và kinh nghiệm của các phẫu thuật viên đã được nâng lên do vậy chỉ định rộng rãi hơn. Tỷ lệ u dạng lạc nội mạc tử cung năm 2010 là 11,5\%, năm 2020 tăng lên là 16,1\%, tỷ lệ này tương đương với nghiên cứu của Phạm Thị Thanh Quỳnh năm 2001 là 10\%, năm 2010 là 18,5\% [4]. Bệnh nhân được chẩn đoán u lạc nội mạc tử cung khi vào ổ bụng tiểu khung thường rất dính nên những năm đâuu triển khai nội soi thường rất ít được chỉ định, hiện nay các phẫu thuật viên thây rằng u lạc nội mạc mổ nội soi ưu việt hơn so với mổ mở vì gỡ dính dễ dàng và câm máu tốt hơn, ít tổn thương nhất và không làm tổn hại nhiều đến mô buô̂ng trứng. Tuy nhiên những trường hợp dính nhiều vào các tạng khác vẫn phải mổ mở. Năm 2010 không có trường hợp nào u nang nhày giáp biên và ung thư, năm 2020 có 03 trường hợp u nang ngày giáp biên lành tính và 01 trường hợp ung thư biểu mô buông trứng, trường hợp này trước mổ không nghi ngờ ung thư: Bệnh nhân 47 tuổi, đau tức hạ vị, kinh nguyệt đều, toàn trạng bình thường, khám u bên trái kích thước khoảng 7cm, di động dê̂. Siêu âm thây bờ khối u rõ, thành mỏng, trống âm, bên trong có nhú, không có dich ổ bunng, CA-125 là $28 \mathrm{UI} / \mathrm{l}$. Khi nội soi thấy u có kích thước khoảng $7 \mathrm{~cm}$, không dính, bề mặt nhẵn, không tăng sinh mạch, cùng đồ không có dịch, tiến hành cắt buồng trứng. Sau khi có kết quả giải phẫu bệnh trả lời ung thư biểu mô buồng trứng. Ở trường hợp này, nghi ngờ duy nhất là dấu hiệu tính chất u trong siêu âm là trống âm có nhú. Khi có nhú thì thường hay nghĩ đến ung thư mặc dù có cũng có nhiều trường hợp siêu âm có nhú nhưng khi mổ lây u làm giải phẫu bênh cho kết quả lành tính. Tuy vâyy nếu như bểnh nhân này được làm thêm một số xét nghiệm cận lâm sàng khác như CT Scanner, cộng hưởng từ... có thể hỗ trợ phát hiện được ung thư trước mổ. Hiện tại bểnh viện phụ sản Thái Bình mới chỉ có duy nhất xét nghiệm $C A$ 125. Đây cũng là sự hạn chế của bệnh viện, chúng tôi hy vọng trong tương lai gẩn sẽ có được trang thiết bị cần thiết phục vụ chẩn đoán cho người bệnh.

4.2. Xử trí UBT trong mổ và kết quả. Kết quả nghiên cứu cho thây năm 2010 cắt u chiếm tỷ lệ cao nhất ở kích thước u <50mm, 50- 
$100 \mathrm{~mm}$; tỷ lệ bóc u cao nhất ở nhóm kích thước u <50mm chiếm tỷ lệ 20,8\%, không có trường hợp nào bóc u ở nhóm kích thước $>100 \mathrm{~mm}$. Nằm 2020 , nhóm kích thước $<50 \mathrm{~mm}$ và 50 $100 \mathrm{~mm}$ đều có tỷ lệ bóc u cao nhất lần lượt là $89,8 \%$ và $68,4 \%$, nhóm kích thước $u>100 \mathrm{~mm}$ bóc u chỉ chiếm $25 \%$ còn lại là cắt u và cắt phần phu là $50 \%$ và $25 \%$. Như vây kích thước khối u phản ánh rõ thái độ xử trí. Khối u có kích thước nhỏ quá trình phẫu thuật bóc u sẽ dễ dàng hơn, buồng trứng ít bị tổn thương hơn do đó tỉ lệ bảo tồn buồng trứng cũng đạt kết quả tốt hơn. Trình độ phẫu thuật viên được nâng cao góp phần vào lựa chon hướng xử trí trong mổ là bóc u bảo tồn phần lành buồng trứng, đem lại lợi ích cho bệnh nhân nhất là các bệnh nhân trẻ tuổi, còn nhu cầu sinh đẻ. Năm 2010 tỷ lệ cắt u là cao nhất ở cả 2 nhóm không dính và dính ít lần lượt là $73,8 \%, 70,6 \%$, không có trường hợp nào dính nhiêu; tỷ lệ bóc u giữa nhóm không dính và dính ít là $17,5 \%$ và $17,6 \%$, không có trường hợp nào dính nhiều; tỷ lệ cắt phần phụ ở nhóm không dính là $8,7 \%$, nhóm dính ít là $11,8 \%$, có 2 trường hợp dính nhiều tuy nhiên đã chuyển sang mổ mở. Năm 2020, bóc u chiếm tỷ lệ cao nhất ở cả hai nhóm không dính và dính ít lần lượt là $72,5 \%$ và $75 \%$, dính nhiều có 1 trường hợp chiếm tỷ lệ $14,3 \%$; cắt u ở nhóm không dính là $14,9 \%$, nhóm dính ít là $16,7 \%$, nhóm dính nhiều là $28,6 \%$, cắt phần phụ ở nhóm không dính, dính ít, dính nhiêu lần lượt là: $12,6 \%, 8,3 \%, 57,1 \%$. Như vậy ở nhóm không dính và dính ít năm 2010 chủ yểu là cắt $u$, năm 2020 chủ yếu là bóc $u$, còn ở nhóm dính nhiều cả 2 năm chủ yếu là cắt phần phụ (02 trường hợp chuyển mổ mở của năm 2010 đều cắt phần phụ). Qua kết quả nghiên cứu thấy rõ được sư phát triển manh mẽ của phẫu thuâat nội soi, những năm đầu triển khai phẫu thuật nội soi chủ yếu là mổ cắt $u$ và thường chỉ định những ca bệnh dễ không dính hoặc dính ít. Đến năm 2020 kết quả cho thấy hầu hết phẫu thuật nội soi u buồng trứng là bóc u ở cả nhóm khổng dính và dính ít, tuy nhiên nhóm dính nhiều thì vẫn còn hạn chế, tỷ lệ cắt u và cắt phần phụ còn cao, nhưng đây thực sự đã là bước phát triển lớn trong ứng dụng phẫu thuật nội soi ở bệnh viện chúng tôi.

Năm 2010, thời gian phẫu thuật trung bình của nhóm không dính là 48,81 $\pm 14,55$ phút, nhóm dính ít 54,33 \pm 9,60 phút, không có nhóm dính nhiều. Thời gian giữa 2 nhóm này không có có sự khác biệt nhiều do việc chỉ định phẫu thuật nội soi điều trị u buồng trứng năm 2010 còn trong diện hẹp về độ di động, tức là hầu hết chỉ đinh những trường hợp u buồng trứng có độ di động dễ hoặc xem xét chỉ định những trường hợp di dộng hạn chế và chống chỉ định những trường hợp khồng di động. Năm 2020, thời gian trung bình của nhóm không dính là 39,26 $\pm 9,82$ phút, nhóm dính ít là $47,76 \pm 18,50$ phút, nhóm dính nhiều là $123,94 \pm 12,69$ phút. Thời gian trung bình giữa 3 nhóm có sự khác biệt lớn điều này càng khẳng định thời gian phẫu thuật tăng lên theo mức độ dính, dính càng nhiêu thì mổ càng khó khăn, nguy cơ tai biến càng cao vì vậy các phẫu thuât viên càng phải cẩn thân làm từng thì, từng bước để đảm bảo độ an toàn cao nhất cho người bệnh do đó cần phải mất nhiều thời gian nhiều hơn. Kết quả nghiên cứu cho thây năm 2020 không có ca tai biến nào, năm 2010 có 2 ca tai biến chiếm 1,6\%. Một trường hợp tụ máu thành bụng lỗ chọc trocart sau mổ 2 giỡ đã் được xử trí tại phòng hậu phẫu rạch lấy khối máu tụ, khâu cầm máu. Một trường hợp chảy máu sau mổ bóc u buồng trứng phát hiện sau mổ giờ thứ 4 được chỉ định nôi soi thây diện bóc u có 2 vị trí chảy máu, đốt cầm máu bằng dao điện hai cực.

Qua nghiên cứu cho thấy số ngày nằm viện chủ yếu $\leq$ 4ngày, năm 2010 là 52,5\%, năm 2020 là $92,6 \%$. Từ 4-7ngày năm 2010 là 47,5\%, năm 2020 là $7,4 \%$. Không có trường hợp nào nằm viện $1-2$ ngày có lẽ do các bác sỹ thận trọng hơn khi theo dỗi hậu phẫu. Khi thu thập số liệu chúng tôi thây hầu hết sau hậu phẫu 3 ngày các bác sỹ cho bệnh nhân xuất viện đặc biệt là năm 2020 gần như sau hậu phẫu 3 ngày bểnh nhân được xuất viện, một số trường hợp bênh nhân phải ở lại từ 4-7 ngày là do tình trạng viên dính nên cần phải nằm lại để điều trị đủ kháng sinh và theo dõi nguy cơ nhiễm trùng. Năm 2010 tỷ lệ năm viện tữ 4-7 ngày còn cao chiếm $47,5 \%$ do những năm đầu triển khai phẫu thuật nội soi nên sau mổ các bác sỹ thường theo dõi rất cẩn thận các nguy cơ và hầu như đều cho bệnh nhân điều trị kháng sinh 5 ngày, một số ít trường hợp bệnh nhân có diễn như cao huyết áp, đau đầu... thì nằm lại khoảng 7 ngày rồi xuất viên. Qua số liệu trên ta thấy so với mổ mở thời gian nằm viện của phẫu thuật nội soi ngắn hơn nhiều do thời gian hồi phục nhanh vì ít đau, ít stress sau mổ cũng như ăn uống được sớm hơn, toàn bộ quá trình chữa bệnh nhanh hơn. Đây là một lợi thế của phẫu thuật nội soi mà phẫu thuật mổ mở không thể đáp ứng được.

\section{KẾT LUÂ̂N}

Phẫu thuâtt nội soi ngày càng được ứng dụng rộng rãi trong xử trí u buồng trứng, hướng xử trí 
trong mổ phụ thuộc nhiều vào tuổi bệnh nhân và tính chất u trong mổ. Phẫu thuật nội soi tại bệnh viện Phụ Sản Thái Bình ngày càng phát triển, năm $2020(71,2 \%)$ cao hơn hẳn so với năm 2010 là $33,9 \%$.

\section{TÀI LIỆ THAM KHẢO}

1. Christopher D.M. Fletcher (2002), Tumors of the ovary. Diagnostic Histopathology of tumors, 2nd edition, Vol 1. Churchill Livingstone; 567-587.

2. Nguyến Bá Đức, Bùi Diệu (2010), Tình hình mắc ung thư tại Việt Nam năm 2010 qua số liệu của 6 vưng ghi nhận giai đoạn 2004-2008, Tạp chí ung thư học Việt Nam, 1-2010, p.73-80.
3. Phạm Văn Mẫn (2007), "Nhận xét chẩn đoán, điều trị u và nang thực thể buồng trứng lành tính tai Bếnh viên Phu Sản Trung ương trong 2 năm 1996 và 2006", Luận văn thạc sỹ y học, Trường Đai học Y Hà Nối.

4. Phạm Thị Thanh Quỳnh (2012), "Nghiên cứu điều trị u nang buồng trứng bằng phẫu thuật nội soi trong 2 năm 2001 và 2010". Luận văn Thạc sỹ y học, Trường Đại học Y Hà Nội.

5. Marana, R., Muzii, L., Catalano, G. F., Caruana, P., Oliva, C., \& Marana, E. (2004). Laparoscopic excision of adnexal masses. The Journal of the American Association of Gynecologic Laparoscopists, 11(2), 162-166.

\title{
ĐĂC ĐIỂM LÂM SÀNG, CÂN LÂM SÀNG VIÊM KẾT MẠC DỊ ỨNG THỂ THEO MÙA, QUANH NĂM TẠI BỆNH VIÊ̂N MẮT NGHỆ AN
}

\author{
Nguyễn Hữu Lê*, Phan Trọng Dũng**, Dư Hải Nam**
}

\section{TÓM TẮT}

Các hình thái lâm sàng của bệnh viêm kết mạc dị ứng bao gồm: viêm kết mạc di ứng theo mùa, viêm kết mạc dị ứng quanh năm, viêm kết mạc mùa xuân, viêm kết mạc chàm cơ địa, viêm kết mạc có nhú gai khổng lồ. Thể viêm kết mạc theo mùa hay gặp nhất và có xu hướng tiến triển thành viêm kết mạc quanh năm, mạn tính. Nghiên cứu mô tả cắt ngang trên 62 đối tượng được chẩn đoán xác định là viêm kết mạc dị ứng theo mùa và viêm kết mạc dị ứng quanh nămtai Bệnh viện Mắt Nghệ An năm từ tháng 4/1999 đển tháng 8/2020 nhắm mục tiêu mô tả đặc điểm lâm sàng, cận lâm sàng kèm theo. Kết quả cho thấy số bệnh nhân viêm kết mạc dị ứng theo mùa là 49 (79\%), 13 bệnh nhân viêm kết mạc dị ứng quanh năm $(21 \%)$. Trong đó 35 (56,5\%) là nam giới, $27(43,5 \%)$ là nữ giới với độ tuối trung bình là 22,02 tuổi. Bệnh nhân tập trung nhiều ở nhóm tuổi $\geq 19$ (50\%), tiếp theo ở nhóm tuổi 6-11 tuổi $(33,9 \%)$. Triệu chứng lâm sàng $100 \%$ bệnh nhân có ngứa, tiếp theo là các triệu chứng chảy nước mắt, kết mạc cương tư ở các mức độ. Triệu chứng sợ ánh sáng và viêm chấm nông biểu mô ít gặp, chỉ mức độ nhẹ hoặc không có.Có 58 bệnh nhân $(93,5 \%)$ dị ứng với từ 2 loại dị nguyên trở lên, mạt bụi nhà $\mathrm{Df}, \mathrm{Dp}, \mathrm{Bt}$ và Gián Mỹ là các loại di nguyên gây dị ứng hay gặp. Có $79 \%$ bệnh nhân bị khổ cả hai mắt, có thời gian võ phim nước mắt ngắn. Nghiên cứu đã chỉ ra được các triệu chứng phổ biến của thể bệnh viêm kết mạc dị ứng theo mùa và quanh năm, từ đó góp phần gợi ý hoạch định đưa ra giải pháp điều trị phù hợp, đạt hiệu quả.

*Sở Y tế Nghê An,

**Bệnh viện Mắt Nghê An

Chịu trách nhiệm chính: Nguyễn Hữu Lê

Email: lebvmna@gmail.com

Ngày nhận bài: 11.8.2021

Ngày phản biên khoa học: 6.10 .2021

Ngày duyệt bài: 15.10 .2021
Tư khóa: Viêm kết mạc dị ứng, Viêm kết mạc dị ứng theo mùa, Viêm kết mạc dị ứng quanh năm.

\section{SUMMARY \\ CLINICAL AND SUBCLINICAL CHARACTERISTICS OF SEASONAL CONUUNCTIVITIS, PERENNIAL CONUUNCTIVITIS AT NGHE AN EYE HOSPITAL}

The clinical manifestations of allergic conjunctivitis include: seasonal allergic conjunctivitis, perennial allergic conjunctivitis, spring conjunctivitis, atopic eczema conjunctivitis, giant papillary conjunctivitis. Seasonal conjunctivitis is most common and tends to progress to chronic, year-round conjunctivitis. A crosssectional descriptive study on 62 subjects with a confirmed diagnosis of seasonal allergic conjunctivitis and perennial allergic conjunctivitis at Nghe An Eye Hospital in the year from April 1999 to August 2020 with the aim to describe the accompanying clinical and paraclinical characteristics. The results showed that the number of patients with seasonal allergic conjunctivitis was 49 (79\%), 13 patients with perennial allergic conjunctivitis (21\%). Of which 35 $(56.5 \%)$ are men, $27(43.5 \%)$ are women with the average age of 22.02 years. Patients were concentrated in the age group $\geq 19(50 \%)$, followed by the age group 6-11 years old (33.9\%). Clinical symptoms $100 \%$ of patients have pruritus, followed by tearing, conjunctival edema to varying degrees. Symptoms of photophobia and superficial epithelitis are uncommon, only mild or absent. There were 58 patients $(93.5 \%)$ allergic to 2 or more types of allergens, house dust mites Df, Dp, Bt and American cockroaches were common allergens. There are $79 \%$ of patients with dry eyes in both eyes, with a short tear film break up time. The study has shown the common symptoms of seasonal and perennial allergic conjunctivitis, thereby contributing to the planning of an appropriate and effective treatment solution.

Keywords: Allergic conjunctivitis, Seasonal allergic conjunctivitis, Perennial allergic conjunctivitis. 